\title{
Kompetensi Guru dalam Penerapan Budaya pada Lembaga PAUD di Indonesia
}

\author{
Made Ayu Anggreni ${ }^{\bowtie}$, Syarif Sumantri ${ }^{2}$, Nurbiana Dhieni², Karnadi ${ }^{2}$ \\ Pendidikan Anak Usia Dini, Universitas PGRI Adi Buana Surabaya, Indonesia(1) \\ Pendidikan Anak Usia Dini, Universitas Negeri Jakarta, Indonesia(2) \\ DOI: $\underline{10.31004 / o b s e s i . v 6 i 2.1585}$
}

\begin{abstract}
Abstrak
Faktor globalisasi menjadi salah satu faktor yang sangat berpengaruh terhadap kondisi internal Indonesia. Sekarang banyak budaya atau kebiasaan dan kepercayaan dari luar yang masuk ke Indonesia tanpa melalui penyaringan padahal seharusnya masyarakat dapat memilih mana yang baik dan mana yang buruk. Pendidikan yang berkualitas dapat menjadi benteng bagi anak-anak dari hal-hal negatif. Penelitian ini bertujuan untuk mendeskripsikan kompetensi guru dalam praktik penerapan budaya pada Lembaga PAUD di Indonesia. Metode penelitian dengan literature review dan menggunakan PRISMA Checklis dilakukan pada bulan Maret - Mei 2021 dan jurnal 20 tahun terakhir, sumber data sekunder artikel jurnal bereputasi baik nasional maupun internasional pada lima database dengan kriteria kualitas tinggi dan sedang, yaitu Scopus, Tandfonline, Research Gate, SagePub dan Schoolar dengan tema kompetensi guru dan tenaga pendidik terlibat menjadi pembelajar dari berbagai komunitas budaya di mana siswa mereka berasal, berkembang sebagai pendidik yang kompeten secara budaya. Hasil penelitian menunjukkan bahwa guru anak usia dini harus berkomitmen untuk mengembangkan pendidikan usia dini yang dapat terlibat dalam pedagogi yang adil dalam praktik pengajaran multikultural. Kualitas suatu pendidikan ditentukan dari berhasil tidaknya guru dalam menyampaikan materi.
\end{abstract}

Kata Kunci: kompetensi; guru; lembaga pendidikan anak usia dini

\begin{abstract}
The globalization factor is one of the most influential factors in Indonesia's internal conditions. Now, there are many cultures or customs and beliefs from outside that enter Indonesia without going through filtering when people should be able to choose which ones are good and which ones are bad. Quality education can be a fortress for children from negative things. This study aims to describe the competence of teachers in the practice of implementing culture at PAUD institutions in Indonesia. The research method with literature review and using the PRISMA Checklist was carried out in March-May 2021 and the last 20 years journals, secondary data sources of reputable journal articles both nationally and internationally in five databases with high and medium quality criteria, namely Scopus, Tandfonline, Research Gate, SagePub and Scholar with the theme of teacher competence and teaching staff are involved in becoming learners from various cultural communities where their students come from, developing as culturally competent educators. The results show that early childhood teachers must be committed to developing early childhood education that can engage in fair pedagogy in multicultural teaching practices. The quality of education is determined by the success or failure of the teacher in delivering the material.
\end{abstract}

Keywords: competency; teachers; early childhood education institutions

Copyright (c) 2022 Made Ayu Anggreni, et al.

$\triangle$ Corresponding author:

Email Address : ayudekayu@gmail.com (Surabaya, Jawa Timur, Indonesia)

Received 29 June 2021, Accepted 26 July 2022, Published 20 February 2022 


\section{PENDAHULUAN}

Dalam program pendidikan guru anak usia dini, realitas sistem pendidikan harus dipahami dan calon guru harus siap menghadapi tantangan yang dihadapi sekolah saat ini. Dasar pemikiran dan penerapan prinsip-prinsip pendidikan guru berbasis praktik disajikan dalam artikel ini. Program pendidikan guru berbasis praktik menawarkan pengalaman bagi kandidat untuk mulai memahami kompleksitas pengajaran dan mengintegrasikan pengetahuan dari teori pembelajaran dan perkembangan ke dalam praktik. Teori Praktik mengidentifikasi tiga konsep kunci tentang bagaimana calon pengajar memahami praktik pengajaran yang kompleks: representasi praktik, penguraian praktik, dan perkiraan praktik (Vartuli et al., 2016). ASDEP PAUD, Kementerian Koordinator Bidang Pembangunan Manusia Dan Kebudayaan, Deputi Bidang Koordinasi Pendidikan dan Agama menjelaskan mengenai kompetensi sebagai suatu pengetahuan, keterampilan, dan perilaku yang harus dimiliki, dihayati, dan dikuasai oleh seseorang dalam melaksanakan pekerjaan. Seperti yang dikemukakan Freire (Brown \& Weber, 2016), tugas guru, yang juga seorang pembelajar, sangat menyenangkan dan keras, menuntut keseriusan dan persiapan ilmiah, fisik, emosional, dan afektif. Tugas yang mengharuskan mereka berkomitmen untuk mengajarkan bagaimana mengembangkan kasih sayang, tidak hanya pada orang lain tetapi juga pada proses yang tersirat dalam pengajaran.

Menyelidiki karakteristik guru pra-jabatan pendidikan anak usia dini (PAUD) guru bantu (Preservice Teachers/PSTs) yang diidentifikasi sebagai berpikiran tertutup dan kapasitas mereka untuk menangani masalah kontroversial, mengingat dominasi keyakinan yang tertanam di PSTs atas prinsip-prinsip yang mereka pelajari di kursus mereka, program persiapan guru juga harus mempertimbangkan disposisi pemikiran terbuka sebagai salah satu kriteria penerimaan PSTs ketika mereka menerima program jika mereka ingin calon guru mendukung prinsip-prinsip inti demokrasi keadilan, martabat, dan kebaikan bersama (Bautista et al., 2018). Refleksi guru tentang konsep-konsep dalam kaitannya dengan praktik sangat signifikan di lapangan, menghubungkan konsep dengan hak-hak anak dan realitas praktik sehari-hari di pendidikan dan perawatan anak usia dini, sebagai perantara atau saluran untuk partisipasi dalam lingkungan pembelajaran awal, sikap profesional guru berkesempatan untuk mendengarkan anak-anak dengan lebih baik (Mentha et al., 2015). Pemahaman tentang kompleksitas dan keterkaitan dalam pengaturan, dapat menghasilkan implementasi kebijakan yang lebih konsisten dan jelas. Sejalan dengan Vartuli et al., (2016), Program pendidikan guru berbasis praktik ini, yaitu praktik epistemik dialami dalam hubungannya satu sama lain, memungkinkan kandidat untuk mengeksplorasi dan mempertanyakan fenomena tertentu tentang proses belajar mengajar (inkuiri terfokus), mengamati proses belajar mengajar tentang fenomena tersebut (observasi terarah), berpartisipasi dalam perencanaan dan pelaksanaan pengajaran (praktik terbimbing), mendekon-struksi pengalaman dan menciptakan makna (inkuiri terfokus) diikuti dengan observasi terarah dan/kesempatan untuk memerankan kembali.

Guru menggabungkan informasi dari berbagai sumber saat mereka membentuk ekspektasi akademis mereka untuk anak usia dini. Ada beberapa faktor yang berkontribusi pada pembentukan ekspektasi pendidik di Taman Kanak-Kanak sehari penuh, dan guru tentang filosofi pengajaran, peran, dan praktik pengajaran, serta interaksi yang mendukung anak usia dini dalam memenuhi ekspektasi kurikulum untuk hasil akhir anak salah satunya yaitu welas asih (Timmons, 2018). Welas asih mengacu pada perhatian, perasaan, dan tindakan untuk meringankan penderitaan pada orang lain. Menjadi salah satu keterampilan sosial-emosional dan budaya yang penting, yang mengejutkan hanya sedikit yang diketahui tentang perilaku welas asih guru PAUD, dan kemampuan mereka untuk mengajarkannya kepada anak-anak. Perilaku guru berpengaruh positif terhadap kepribadian guru (Sarjana \& Khayati, 2017). Secara keseluruhan, penelitian tentang kasih sayang di lingkungan pendidikan dan pengasuhan anak usia dini (ECEC/early childhood education and care) masih langka. 
Penelitian yang ada menunjukkan bahwa keterampilan welas asih dapat diperoleh melalui pelatihan, dan kemampuan welas asih yang kolektif dapat dikembangkan dengan praktik sehari-hari. Welas asih dapat dipandang sebagai salah satu kekuatan karakter, keterampilan umum, atau yang digarisbawahi dalam kurikulum terbaru dan dokumen pedagogis, 95 kepala sekolah PAUD berpartisipasi dalam intervensi, yang bertujuan untuk mempromosikan kasih sayang, kekuatan karakter, dan budaya organisasi yang mendukung (Vuorinen et al., 2021).

Pada sistem pengajaran, kompetensi digunakan untuk mendeskripsikan kemampuan profesional yaitu kemampuan untuk menunjukan pengetahuan dan konseptualisasi pada tingkat yang lebih tinggi. Kompetensi ini dapat diperoleh melalui pendidikan, pelatihan, dan pengalaman lain sesuai tingkat kompetensinya. Mengajar sebagai karya budaya berarti mengambil sikap sebagai pembelajar, penanya, dan mengaburkan garis guru dan pembelajar, secara terus-menerus dialogis, baik dalam mengajar maupun dalam pendidikan guru. Ladson - Billings mengatakan ini mencakup menjadi siswa - siswi Anda, (Brown \& Weber, 2016), tidak hanya belajar dari mereka, tetapi mempelajarinya dengan cermat. Bagaimanapun, mereka tidak memiliki tanggung jawab untuk mengajari kita tentang diri mereka sendiri; kitalah yang harus belajar tentang mereka, keluarga mereka, dan komunitas mereka, bahkan jika mereka sudah dewasa.

Guru perlu membantu praktik dan guru bantu yang bekerja dalam konteks ini dengan merumuskan tanggapan instruksional yang menangani tuntutan berisiko tinggi pembuat kebijakan, dengan mempertimbangkan praktik terbaik anak usia dini, dan memperhatikan linguistik, budaya anak-anak, atau budaya lokal pada pengajaran mereka sambil mencoba merumuskan pengalaman belajar yang mencerminkan dunia sosiokultural anak usia dini (Brown \& Weber, 2016). Guru merupakan pendidik profesional dengan tugas utama mendidik, mengajar, mengarahkan, melatih, menilai, mengevaluasi peserta didik pada pendidikan anak usia dini (Mariyana, 2007). Hasil penelitian menunjukkan pertama, kualifikasi akademik seorang guru PAUD mempengaruhi kemampuan, pengetahuan serta pemahaman guru terhadap peserta didik. Kedua, masih banyak lembaga PAUD yang kurang memiliki kemampuan dalam menyusun perencanaan pembelajaran yang menyenangkan serta pemahaman akan pentingnya penyusunan perencanaan pembelajaran masih minim. Ketiga, minimnya kompetensi pedagogik yang dimiliki akhirnya mempengaruhi proses pembelajaran yang berkualitas bagi anak, pembelajaran menjadi tidak menyenangkan serta penilaian pembelajaran yang dilakukan guru belum dapat menggambarkan perkembangan yang mencakup segala aspek perkembangan anak (Sum \& Taran, 2020). Namun demikian sarana prasarana dan lingkungan kerja berpengaruh bersama-sama terhadap kinerja guru (Angrainy et al., 2020). Oleh karena itu, penting untuk dibahas lebih lanjut mengenai kompetensi guru dalam praktik penerapan budaya pada Lembaga PAUD di Indonesia.

\section{METODOLOGI}

Penelitian ini merupakan penelitian literature review dan akan menggunakan PRISMA checklist untuk menentukan penyeleksian studi yang telah ditemukan dan disesuaikan dengan tujuan dari literature review (Nursalam, 2020). Pencarian literature dilakukan pada bulan Maret - Mei 2021. Pemilihan sumber mengacu pada publikasi mana yang harus ditargetkan, serta strategi pencarian pada definisi istilah dan jangka waktu yang akan dibahas (Hariyanti et al., 2020). Data yang digunakan dalam penelitian ini merupakan data sekunder yang diperoleh bukan dari pengamatan langsung, akan tetapi diperoleh dari hasil penelitian yang dilakukan oleh peneliti terdahulu (Nursalam, 2020). Sumber data sekunder didapat berupa artikel jurnal bereputasi baik nasional maupun internasional dengan tema kompetensi guru dan tenaga pendidik terlibat menjadi pembelajar dari berbagai komunitas budaya di mana siswa mereka berasal, berkembang sebagai pendidik yang kompeten secara budaya. Pencarian literature review menggunakan lima database dengan kriteria kualitas tinggi dan sedang, yaitu Scopus, Tandfonline, Research Gate, SagePub dan Schoolar. Data dalam penelitian ini diperoleh dari kajian 
literature jurnal 20 tahun terakhir. Alur tahapan dalam melakukan studi literature pada penelitian ini dengan menggunakan tahapan seperti gambar 1.

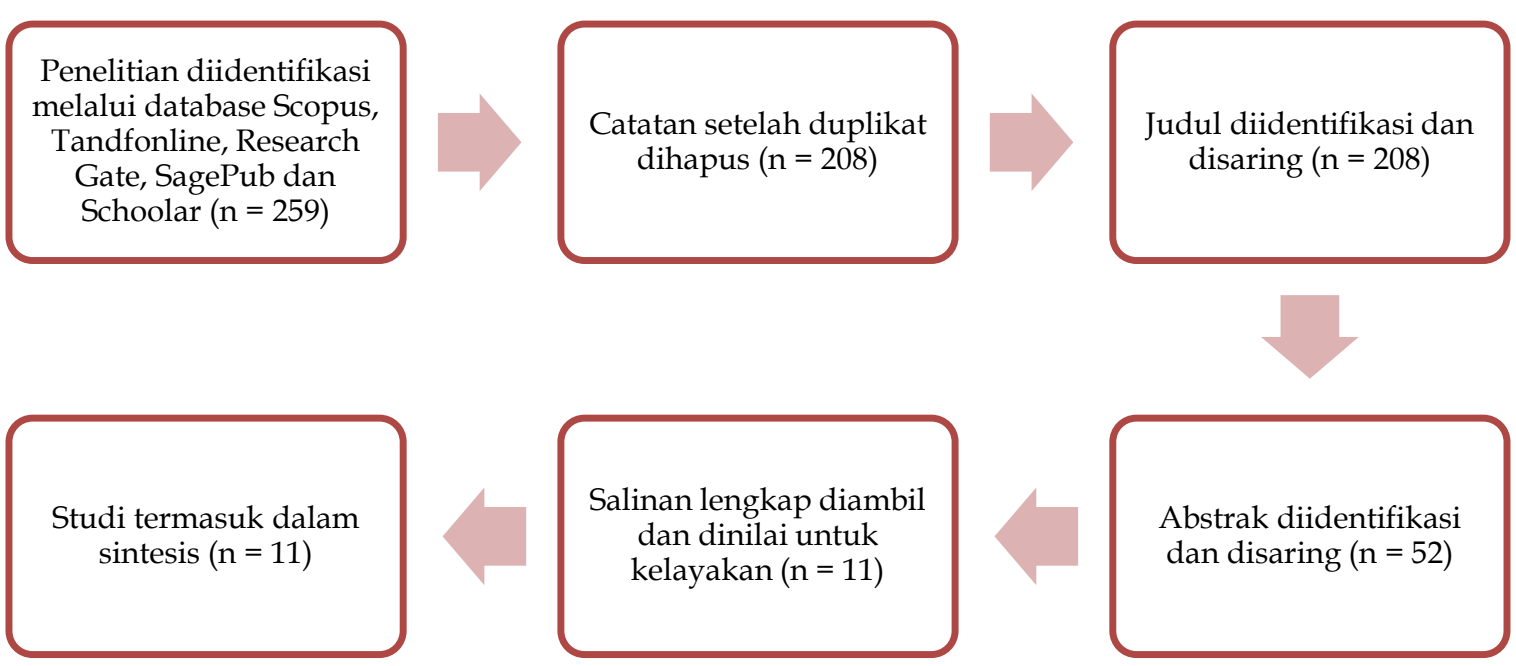

Gambar 1. Diagram Flow literature Review Berdasarkan PRISMA (Nursalam, 2020).

Analisis kualitas metodologi dalam setiap studi $(n=11)$ dengan checklist daftar penilaian dengan beberapa pertanyaan untuk menilai kualitas dari studi kompetensi guru berkembang sebagai pendidik yang kompeten secara budaya. Penilaian kriteria diberi nilai 'ya', 'tidak', 'tidak jelas' atau 'tidak berlaku', dan setiap kriteria dengan skor 'ya' diberi satu poin dan nilainya adalah nol, setiap skor studi kemudian dihitung dan dijumlahkan skor penelitian setidaknya 50\% memenuhi kriteria critical appraisal dengan nilai titik cut-off yang telah disepakati peneliti. Di kolom pertama di sepanjang sumbu vertical tabel, cantumkan penulis dan tanggal publikasi untuk setiap studi (Ramdhani et al., 2014). Dalam skrining terakhir, delapan belas studi mencapai skor lebih tinggi dari 50\% dan siap untuk melakukan sintesis data, akan tetapi karena penilaian terhadap resiko bias, dua studi dikeluarkan dan artikel yang digunakan dalam literature review terdapat 11 buah.

\section{HASIL DAN PEMBAHASAN}

\section{Perbandingan Penerapan Budaya Dengan Praktik Yang Terjadi Di Indonesia}

Lanskap demografi pendidikan guru saat ini tidak optimis. Hanya seperempat individu dalam program pendidikan guru di institusi pendidikan tinggi Amerika yang berkulit hitam Departemen Pendidikan AS dalam (Brown \& Weber, 2016) dan jumlahnya berkurang karena calon guru menghadapi kenyataan memasuki profesi dengan gaji rendah. Selain itu, guru kulit berwarna memiliki tingkat atrisi yang jauh lebih tinggi daripada guru kulit putih. Dengan demikian, mereka cenderung tidak bersedia memilih menjadi profesi guru dan lebih cenderung meninggalkan profesinya dalam beberapa tahun pertama mengajar menurut Achinstein, Ogawa, Sexton, \& Freitas dalam (Brown \& Weber, 2016). Hal ini juga mencerminkan pengetahuan kita tentang pengasuhan dan pendidikan anak usia dini yang didasarkan pada paradigma bermasalah yang membingkai anak-anak kulit berwarna, yang secara inheren dipandang inferior, terpinggirkan secara budaya (kurang pendidikan yang layak), dan berbeda (dari norma), seperti yang dijelaskan oleh Goodwin et al., dalam (Brown \& Weber, 2016). Guru di Indonesia untuk menerapkan proses pembelajaran dan pengalaman mempengaruhi perkembangan kecerdasan anak diantaranya dengan pembelajaran berbasis multiple intelligences. Karakteristik yang dipilih melalui proyek pembelajaran berbasis budaya lokal untuk merangsang kecerdasan anak, akan memberikan variasi yang menyenangkan dalam suasana belajar. Pembelajaran proyek yang diterapkan guru melalui sebuah metode yang memberikan kesempatan pada anak mengeksplorasi lima indera serta fisiknya dalam 
melakukan aktivitas tertentu dengan menyenangkan (Widiastuti, 2015). Materi tentang budaya dapat menjadi dasar dalam belajar, serta mengajarkan anak-anak tentang nilai-nilai budaya, sehingga mereka memahami lingkungan budaya (budaya lokal).

Sejak saat yang disebut ilmuwan mengusulkan bahwa ukuran otak orang kulit hitam lebih rendah daripada otak orang kulit putih. Sejak anak-anak kulit berwarna dipandang secara inheren lebih rendah (dan hanya bisa diselamatkan melalui campur tangan ilahi), hingga saat anak-anak kulit berwarna terlihat sebagai kehilangan budaya (dan harus diselamatkan oleh wanita kulit putih, yang menjadi korban mereka), atau berbeda dari norma, secara historis, rasialisasi dan rasisme telah menjadi landasan masyarakat Amerika. Pendidikan yang mempermasalahkan rasisme diperlukan sebagai kejadian alami ungkapan Goodwin et al., Ladson - Billings \& Tate dalam (Brown \& Weber, 2016). Faktanya di Indonesia, Pendidikan tidak bisa dilepaskan dari suatu kebudayaan yang terdapat dalam suatu masyarakat. Undang-Undang Republik Indonesia tahun 2003 tentang Sistem Pendidikan Nasional pada Bab 1 Ketentuan Umum pasal 1 ayat 16 menyebutkan bahwa "Pendidikan berbasis masyarakat adalah penyelenggaraan pendidikan berdasarkan kekhasan agama, sosial, budaya, aspirasi, dan potensi masyarakat sebagai perwujudan pendidikan dari, oleh, dan untuk masyarakat (Pemerintah RI, 2003)

Program pendidikan guru harus mempersiapkan guru anak usia dini untuk dapat terlibat dalam pekerjaan penting untuk ikut serta dalam segala kegiatan dan persepsi ini di ruang kelas masa depan mereka melalui keterlibatan dalam pendidikan multikultural kritis dan pendidikan antirasis dengan siswanya (Barnes-Najor et al., 2021). Pendapat lain mengungkapkan bahwa salah satu kompetensi yang harus dikuasai guru adalah merancang strategi pembelajaran yang akan dilakukan. Keberhasilan pembelajaran yang diciptakan guru akan tergantung pada penguasaan strategi pembelajaran. Pernyataan tersebut memberikan makna bahwa setiap pekerjaan profesional dipersyaratkan memiliki kemampuan atau kompetensi tertentu agar yang bersangkutan dapat melaksanakan tugas-tugas profesionalnya. Sejalan dengan yang dikemukakan oleh Paul Gorski dalam (Brown \& Weber, 2016), "Beberapa orang mendiskusikan pendidikan multikultural sebagai perubahan dalam kurikulum, mungkin sesederhana menambahkan materi dan perspektif baru dan beragam agar lebih inklusif terhadap kelompok yang secara tradisional kurang terwakili." Dalam bagian ini, kami mendefinisikan pendidikan multikultural secara kritis, menyangkal definisi reduksionis dan problematis dari pendidikan multikultural, seperti "pendekatan pahlawan dan liburan," yang terlalu menyederhanakan budaya, kehidupan, dan kemanusiaan. Menegaskan bahwa pendidikan multikultural merupakan bidang studi yang dirancang untuk meningkatkan pemerataan pendidikan bagi semua (Barnes-Najor et al., 2021). Lebih lanjut, mereka menggarisbawahi bagaimana pedagogi kesetaraan merupakan aspek penting dari pendidikan multi budaya.

James Banks mengemukakan bahwa pendidikan multikultural memiliki lima dimensi: integrasi konten, konstruksi pengetahuan, pedagogi ekuitas, pengurangan prasangka, dan pemberdayaan budaya sekolah (Brown \& Weber, 2016). Artinya, konten harus mencerminkan berbagai budaya. Praktik di Indonesia, Pendidik guru perlu membantu guru bantu memahami permasalahan pengetahuan, memodifikasi dan merevisi pedagogi mereka dengan cara yang menumbuhkan kesetaraan. Sikap rasional calon guru dapat dimodifikasi ketika pedagogi didasarkan pada praktik dan pengalaman individu dan komunitas yang secara historis minoritas dan memahami bahwa belajar, berkembang, dan bahkan moral adalah budaya.

Pekerjaan untuk identitas ini sangat mendasar, bagaimanapun, pendidikan multikultural melibatkan pedagogi kesetaraan; itu terdiri dari pengajaran untuk keadilan budaya dan ras. Berangkat dari pekerjaan identitas ini dan fokus pada pemerataan dan keadilan, pendidikan multikultural menjadi sekantong tipu daya yang tidak berarti. Karenanya, di sini bisa menggarisbawahi perlunya memulai dengan perubahan pola pikir, mengambil komitmen untuk melihat dan memahami siapa kami sebagai guru dari perspektif 
budaya. Untuk mempertimbangkan hak istimewa, sebagai guru yang membingkai stereotip yang dimiliki, dan lihat diri kita sendiri sebagai makhluk budaya, yang akan mencintai budaya dengan cara penerapan kearifan lokal melalui pemberian pembelajaran untuk anak usia dini, seperti: berbahasa daerah, permainan tradisional, melatih memainkan musik angklung, berpakaian daerah masing-masing ketika ada hari Nasional. Disamping itu pula dari guru memberikan tauladan kepada anak didik agar menumbuhkan rasa welas asih, suka menolong dan empati, bergotong-royong, gigih \& pantang menyerah, ramah, sopan santun terhadap orang yang lebih tua, cinta tanah air.

\section{Temuan Dan Diskusi Tentang Praktik yang Dapat Dikembangkan Di Indonesia}

Pendidik guru anak usia dini juga harus berkomitmen untuk mengembangkan pendidik usia dini yang dapat terlibat dalam pedagogi yang adil, dalam praktik pengajaran multikultural, tidak melihat apakah mereka orang kulit berwarna atau bukan. Bidang pendidikan guru anak usia dini harus berkomitmen untuk mengembangkan pendidik usia dini yang dapat terlibat dalam praktik budaya terlepas dari identitas ras, pengalaman budaya, hak istimewa, dan penindasan mereka. Ini perlu pemikiran kembali siapa kita sebagai pendidik guru anak usia dini, mengakui bahwa kita adalah makhluk budaya, guru bisa membuat/mengubah kurikulum pendidikan anak usia dini, pengajaran, dan pemrograman dengan cara yang relevan dengan budaya dan kritis (Brown \& Weber, 2016), berkomitmen untuk layanan PAUD termasuk dalam layanan jasa profesional yang dilakukan oleh kalangan profesi guru atau pendidik PAUD yang diatur dalam Undang-Undang Nomor 14 Tahun 2005 tentang guru dan dosen. Sebagai layanan jasa profesional, layanan PAUD dilaksanakan pada berbagai bentuk dan jalur kelembagaan.

Pada rentang usia ini potensi kecerdasan dan dasar-dasar perilaku seseorang terbentuk. Sedemikian pentingnya masa ini sehingga usia dini sering disebut the golden age. Pada masa ini guru memberi rangsangan pendidikan dengan cara bermain sambil belajar. Permainan yang diterapkan sebaiknya menekankan pada budaya lokal daerah setempat, agar dapat melestarikan dan memupuk rasa cinta terhadap budaya sendiri. Menurut (Karwati, 2016), melalui bermain anak beraktivitas dan bersosialisasi dengan lingkungan, mereka mendapatkan pengalaman, pengetahuan dan keterampilan. Sesuai dengan tujuan pendidikan anak usia dini yaitu, anak mampu mengenal lingkungan alam, sosial, peranan masyarakat, dan menghargai keragaman sosial dan budaya serta mampu mengembangkan konsep diri, sikap positif terhadap belajar, control diri dan rasa memiliki.

Dari perspektif pendidikan multikultural yang kritis, mengajar adalah karya budaya. Begitu pula dengan pendidikan guru atau mengajar dalam pendidikan guru, keduanya adalah pekerjaan multikultural, yang membutuhkan penolakan gagasan yang salah tentang kurikulum dan pengajaran sebagai budaya (Brown \& Weber, 2016). Sebuah perilaku baru dan budaya yang tidak sesuai dengan filosofi Indonesia maka dapat memberikan dampak yang tidak baik terhadap perkembangan anak usia dini. Permasalahan ini dapat diatasi salah satunya dengan menanamkan nilai-nilai budaya lokal untuk anak usia dini (Widiastuti, 2015). Pendidikan multikultural kritis memerlukan pembelajaran tentang berbagai perspektif dan sudut pandang, guru dan tenaga pendidik terlibat dalam menjadi pembelajar dari berbagai komunitas budaya di mana siswa mereka berasal, berkembang sebagai pendidik yang kompeten secara budaya (Barnes-Najor et al., 2021). Sejalan dengan itu, pendidikan karakter penting ditanamkan sejak anak usia dini oleh guru PAUD, sebagai cerminan bahwa guru yang berkompeten secara pedagogi didasarkan pada praktik dan pengalaman individu dan komunitas, untuk membentuk pribadi anak yang memiliki nilai-nilai luhur bangsa dan menjadi warga negara yang baik. Pendidikan karakter tidak hanya mencetak anak yang pintar secara kognitif, namun dapat menciptakan anak yang berbudi pekerti luhur.

Guru dapat mengembangkan materi berbasis kearifan lokal dengan berbagai kegiatan pembelajaran yang menarik diharapkan dapat mengembangkan karakter siswa seperti: karakter kerja sama, toleransi, dan sikap peduli. Sepatutnya siswa memiliki sikap yang arif 
dan bijak, dalam memandang kearifan lokal yang dimiliki oleh daerahnya sebagai bagian dari pengembangan pendidikan karakter merupakan bekal dalam hidup bermasyarakat (Rachmadyanti, 2017). Di lembaga PAUD guru mengajak anak usia dini untuk bermain engklek, gobak sodor, menyanyikan lagu daerah serta berkomunikasi dengan Bahasa daerah setempat, atau mendongeng dengan kisah dari suatu budaya daerah, menggunakan bahan atau produk hasil lokal yang digunakan sebagai alat atau sarana pembelajaran. Guru sebaiknya mengenalkan dengan mengunjungi tempat peninggalan budaya bangsa Indonesia seperti, candi mendut, candi Borobudur, monumen, museum sejarah bangsa.

\section{Rekomendasi Berupa Ide Kreatif dan Implementatif Tentang Intervensi Pengembangan Pendidik PAUD.}

Antara kebudayaan dengan pendidikan terdapat komplementer. Pertama, kebudayaan berperan sebagai masukan (input) bagi pendidikan. Contohnya, tujuan pendidikan ditentukan oleh sistem nilai yang dianut oleh masyarakat (wujud pertama kebudayaan), kurikulum dan metode pendidikan, antara lain akan ditentukan oleh nila-nilai, norma-norma, dan gagasan-gagasan masyarakat (wujud pertama kebudayaan), serta ditentukan pula wujud kebudayaan sebagai suatu kelakuan berpola dari suatu masyarakat (wujud kedua kebudayaan), adapun wujud ketiga dalam kebudayaan (wujud fisik berupa bangunan, OHP). Akan menjadi alat bantu dalam praktik pendidikan. Kedua, pendidikan berfungsi untuk melestarikan kebudayaan masyarakat (fungsi konservasi) dan juga berfungsi masyarakat ke arah yang lebih baik (fungsi kreasi atau inovasi). Supriadi (2020) menyatakan bahwa pendidikan bukan hanya tugas sekolah, melainkan tanggung jawab orang tua di rumah. Walaupun kenyataannya banyak orang tua yang kurang peduli apa yang terjadi dengan anak dan dipelajari anak di sekolah (Ekawati \& Iriani, 2020). Pendidikan merupakan sarana dalam mengenalkan nilai budaya pada anak.

Hal yang harus diwariskan ke generasi muda tentunya adalah kebudayaan yang ideal sehingga kebudayan ideal milik masyarakat menjadi lestari. Namun demikian, pendidikan tidak cukup melaksanakan fungsi konservasi saja, sebaliknya pendidikan juga harus melaksanakan fungsi inovasi dan kreasi. Sehingga manfaat materi nilai kearifan lokal, yaitu: 1) memberikan ide kreatif bagi guru untuk mengembangkan materi pendidikan karakter bagi Anak Usia Dini \& Sekolah Dasar yang berbasis kearifan lokal; 2) memotivasi guru dan orang tua untuk mengarahkan siswa menjadi pribadi yang cerdas dan berbudaya; 3) memotivasi semua pihak untuk melestarikan kekayaan budaya yang ada di daerah setempat. Guru harus mengenal serta belajar lebih mendalam tentang budaya sendiri, dan bisa diwariskan atau di terapkan di lembaga tempat kerja, mengajak orang tua, anak didik, serta masyarakat untuk mencintai budaya Indonesia, yang banyak mengandung nilai-nilai kearifan lokal dan merupakan jati diri dari suatu bangsa. Jangan sampai budaya Indonesia seperti tari daerah di klaim oleh bangsa lain, karena anak usia dini sebagai generasi pewaris budaya tidak mengenal, melestarikan dan mencintai budayanya. Penyebabnya adalah karena tergiur dan langsung menerima budaya luar yang baru dikenal, budaya barat atau ketimur-timuran, tidak melalui penyaringan terlebih dahulu.

\section{SIMPULAN}

Pendidikan yang berkualitas dapat menjadi benteng bagi anak-anak dari hal-hal negatif. Kualitas suatu pendidikan ditentukan dari berhasil tidaknya guru dalam menyampaikan materi. Kompetensi guru sebagai suatu pengetahuan, keterampilan, dan perilaku yang harus dimiliki, dihayati, dan dikuasai oleh seseorang dalam melaksanakan pekerjaan. Guru berkomitmen untuk mengembangkan pendidik usia dini yang dapat terlibat dalam praktik budaya terlepas dari identitas ras, pengalaman budaya, hak istimewa, dan penindasan. Kemampuan guru bisa membuat/mengubah kurikulum pendidikan anak usia dini, pengajaran, dan pemrograman dengan cara yang relevan dengan budaya. Cara untuk menangani masalah yang sering terjadi dijaman globalisasi sekarang ini dengan menanamkan 
nilai-nilai budaya lokal untuk anak usia dini. Guru dapat mengembangkan materi berbasis kearifan lokal dengan berbagai kegiatan pembelajaran yang menarik diharapkan dapat mengembangkan karakter siswa seperti: karakter kerjasama, toleransi, dan sikap peduli.

\section{UCAPAN TERIMA KASIH}

Terima kasih ditujukan kepada para partisipan yang terlibat dalam penelitian ini, reviewer yang telah memberikan masukan berharga serta editor Jurnal Obsesi yang telah memfasilitasi penerbitan artikel ini.

\section{DAFTAR PUSTAKA}

Angrainy, A., Fitria, H., \& Fitiani, Y. (2020). Pengaruh Sarana Prasarana dan Lingkungan Kerja terhadap Kinerja Guru. Journal of Education Research, 1(2), 154-159. https://doi.org/10.37985/joe.v1i2.15

Barnes-Najor, J. V., Thompson, N. L., Cameron, A. F., Smith, T. M., Calac Verdugo, M., Brown, P. L., \& Sarche, M. C. (2021). Cultural and Practice Perspectives on the Classroom Assessment Scoring System: Voices From American Indian and Alaska Native Head Start Programs. Journal of Research in Childhood Education, 35(1), 162-183. https:// doi.org/10.1080/02568543.2020.1723749

Bautista, N., Misco, T., \& Quaye, S. J. (2018). Early Childhood Open-Mindedness: An Investigation Into Preservice Teachers' Capacity to Address Controversial Issues. $\begin{array}{llll}\text { Journal of } \quad \text { Teacher } & \text { 154-168. }\end{array}$ https:// doi.org/10.1177/0022487117702575

Brown, C. P., \& Weber, N. B. (2016). Struggling to Overcome the State's Prescription for Practice: A Study of a Sample of Early Educators' Professional Development and Action Research Projects in a High-Stakes Teaching Context. Journal of Teacher Education, 67(3), 183-202. https:// doi.org/10.1177/0022487116636452

Ekawati, E. Y., \& Iriani, A. (2020). Evaluasi Discrepancy Program Parenting Class dalam Rangka Meningkatkan Hubungan Masyarakat. Jurnal Obsesi : Jurnal Pendidikan Anak Usia Dini, 5(1), 117. https://doi.org/10.31004/obsesi.v5i1.525

Hariyanti, N. T., Trianto, E. M., \& Wirapraja, A. (2020). Hubungan Variabel Pemasaran Digital Terhadap Electronic Word Of Mouth (E-WOM): Sebuah Studi Literatur. Teknika, 9(2), 146-155. https://doi.org/10.34148/teknika.v9i2.299

Karwati, E. (2016). Pengembangan Pembelajaran Dengan Menekankan Budaya Lokal Pada Pendidikan Anak Usia Dini. EduHumaniora | Jurnal Pendidikan Dasar Kampus Cibiru, 6(1), 53-60. https://doi.org/10.17509/eh.v6i1.2861

Mariyana, R. (2007). Oleh : Rita Mariyana.

Mentha, S., Church, A., \& Page, J. (2015). Teachers as Brokers: Perceptions of "Participation" and Agency in Early Childhood Education and Care. International Journal of Children's Rights, 23(3), 622-637. https:// doi.org/10.1163/15718182-02303011

Nursalam. (2020). Literature_Systematic_Review_pada_Pendid (1).

Pemerintah RI. (2003). Undang-undang Nomor 20 Tahun 2003 tentang Sistem Pendidikan Nasional.

Rachmadyanti, P. (2017). Penguatan Pendidikan Karakter Bagi Siswa Sekolah Dasar Melalui Kearifan Lokal. Jurnal Pendidikan Sekolah Dasar, 3(2), 201. https://doi.org/10.30870/jpsd.v3i2.2140

Ramdhani, A., Ramdhani, M., \& Amin, A. (2014). Writing a Literature Review Research Paper: A step-by-step approach. International Journal of Basic and Applied Science, 3(01), $47-$ 56.

Sarjana, S., \& Khayati, N. (2017). Pengaruh Etika, Perilaku, Dan Kepribadian Terhadap Integritas Guru. Jurnal Pendidikan Dan Kebudayaan, 1(3), 379. https://doi.org/10.24832/jpnk.v1i3.450 
Sum, T. A., \& Taran, E. G. M. (2020). Kompetensi Pedagogik Guru PAUD dalam Perencanaan dan Pelaksanaan Pembelajaran. Jurnal Obsesi : Jurnal Pendidikan Anak Usia Dini, 4(2), 543. https:// doi.org/10.31004/obsesi.v4i2.287

Supriadi, O. (2020). Peranan Kepala PAUD dalam Penyelenggaraan Pendidikan Sebelum dan Saat Terjadi Pandemi Covid-19. Jurnal Obsesi : Jurnal Pendidikan Anak Usia Dini, 5(1), 841-856. https://doi.org/10.31004/obsesi.v5i1.727

Timmons, K. (2018). Educator Expectations in Full-Day Kindergarten: Comparing the Factors That Contribute to the Formation of Early Childhood Educator and Teacher Expectations. Early Childhood Education Journal, 46(6), 613-628. https:// doi.org/10.1007/s10643-018-0891-0

Vartuli, S., Snider, K., \& Holley, M. (2016). Making it Real: A Practice-Based Early Childhood Teacher Education Program. Early Childhood Education Journal, 44(5), 503-514. https:// doi.org/10.1007/s10643-015-0733-2

Vuorinen, K., Pessi, A. B., \& Uusitalo, L. (2021). Nourishing Compassion in Finnish Kindergarten Head Teachers: How Character Strength Training Influences Teachers' Other-Oriented Behavior. Early Childhood Education Journal, 49(2), 163-176. https:// doi.org/10.1007/s10643-020-01058-0

Widiastuti, S. (2015). Pembelajaran Proyek Berbasis Budaya Lokal untuk Menstimulasi Kecerdasan Majemuk Anak Usia Dini. Jurnal Pendidikan Anak, 1(1), 59-71. https://doi.org/10.21831/jpa.v1i1.2907 